\title{
Sabah State Election 2020: Victory of Alias Haji Sani (WARISAN) at DUN 53 Sekong
}

\author{
Hamdan bin Mohd Salleh*1, Rashidin Idris², Mohd Naqib Lutfi bin Abdul Latif ${ }^{3}$ \\ ${ }^{* 1}$ Associate Professor, Faculty of Education \& Social Sciences, Universiti Selangor (UNISEL), MALAYSIA \\ ${ }^{2} \mathrm{PhD}$ Candidate, Universiti Perguruan Sultan Idris (UPSI), MALAYSIA \\ ${ }^{3}$ Lecturer, Faculty of Education \& Social Sciences, Universiti Selangor (UNISEL), MALAYSIA \\ *(hamdan@unisel.edu.my)
}

\begin{abstract}
This journal is licensed under a Creative Commons Attribution-Noncommercial 4.0 International License (CC-BY-NC). Articles can be read and shared for noncommercial purposes under the following conditions:

- BY: Attribution must be given to the original source (Attribution)

- NC: Works may not be used for commercial purposes (Noncommercial)

This license lets others remix, tweak, and build upon your work non-commercially, and although their new works must also acknowledge you and be non-commercial, they don't have to license their derivative works on the same terms. License Deed Link: http://creativecommons.org/licenses/by-nc/4.0/ Legal Code Link: http://creativecommons.org/licenses/by-nc/4.0/legalcode $A B C$ Research Alert uses the CC BY-NC to protect the author's work from misuse.
\end{abstract}

\section{Abstract}

The Sabah state assembly was dissolved on 30 July 2020 by the Chief Minister Shafie Apdal to prevent a coup by the previous Chief Minister Musa Aman through his "Group 33". The 2020 Sabah State election was held on 26 September 2020 involved a record total of 447 candidates vying for 73 state seats. The main contest was between the WARISAN-PLUS of 5 political parties and a group of 9 political parties under the coalition of the newly minted Gabungan Rakyat Sabah (GRS). GRS managed to wrest the state government by comfortably winning 38 out of 73 seats with additional 3 seat came from pro-GRS independent candidates. Nevertheless, WARISAN managed to retain N53 Sekong even as the incumbent have been dropped after 26 months at the helm. This article studied on issues surrounding the victory of Alias Haji Sani during the election. The findings of this articles use primary data, secondary data, online sources dan participative observation findings. The victory of Alias Haji Sani shows that the influence of people-centric and "Gentlemen Politics Budiman" identification is stronger than political affiliation.

\section{Keywords}

Sabah election, Sekong election, WARISAN

\section{INTRODUCTION}

The Warisan Sabah Party (WARISAN) that was established on 17 October 2016 led the Sabahan state government after the 2018 PRU with Shafie Afdhal as the elected Chief Minister. This government was made up of 29 assemblymen from WARISAN, DAP and KEADILAN (WARISAN/PH) along with 6 assemblymen from BN who joined after the PRU.

The 2020 Sabah state election was one of the effects of The Sheraton Move which overthrew the federal government in February 2020. Musa Aman, the former Chief Minister who lost announced that he has the simple majority to take over the government in a press conference on 29 July 2020 along with 33 assemblymen (also known as Kumpulan 33) including 5 from WARISAN, 1 from UPKO and 1 from 
KEADILAN. To prevent the fall of the state government, Chief Minister Shafie Afdhal received permission from the governor of Sabah to disband the assembly on 30 July 2020 to ensure that an election can be held.

As a result of the DUN dissolution, Sabah's general election was held on 26 September 202073 sets of DUN Sabah. The re-demarcation of politics saw the two main coalitions clash which includes: the WARISAN logo in PRN 2020.

(ii) Gabungan Rakyat Sabah (GRS): Brings together parties under the BN coalition, Perikatan Nasianal (PN) and Parti Bersatu Sabah (PBS). BN Sabah is headed by UMNO whereas PN Sabah is headed by BERSATU.

The 16th PRN Sabah brings together a total of (447) candidates, the highest in history. There has been an addition of DUN seats from 60 to 73 during this general election. One of the hotseats is N53 Sekong which was previously listed as N43. The 6 cornered competition and the action taken by WARISAN to drop the current candidate only after 26 months resulted in this seat becoming the center of attraction.

The decided to hold the election during the pandemic of Covid-19 resulted in low voters' turnout of as low as 66.6 percent or 745,387 votes. Although WARISAN-Plus obtained the popular vote of (43.42\%) more than GRS (43.22\%), the coalition failed to defend the existing government. GRS managed to obtain 38 seats while WARISAN-Plus won 32. The balance of 3 seats was won by an independent candidate which is inclined to GRS. This PRN result enabled GRS to form the state government with 41 seats in total.

Even though WARISAN failed to defend the claim the state government, DUN Sekong was still able to be defended via parti candidate Alias Haji Sani. This paper shall observe from a micro perspective, the success of WARISAN in Sekong where the party placed a new face to replace the former candidate.

\section{"POLITIK BUDIMAN" or GENTLEMEN POLITICS IN SABAH'S DIVERSITY}

There are 42 ethnic and 200 sub-ethnic groups in Sabah with diverse languages, cultures and religion. This condition will surely create various patterns and political sentiments in socio-politics which varies according to the demographic. Throughout Sabah's political history, there are 19 main local political parties who are active and 12 political parties which were disbanded but have enlivened Sabah's politics. This excludes parties at the national level which are also present in Sabah such as $U M N O$, KEADILAN, BERSATU, DAP, AMANAH, PEJUANG, MIC, MCA and GERAKAN.

Sabah's hot political situation where the culture of party hopping which resulted in the collapse of the government can be seen during the 16 PRN which happened in Sabah. This includes 1 PRU and 1 PRN which was held between 2018 until 2020. These conditions call for a new coalition and one of the solutions to look at the various aspects of politic games played in Sabah. As such, there is a need to have valued political foundations which is based on Gentlemen Politics to ensure the people becomes the sole foundation for the administration and operations of the government.

Gentlemen Politics is the brainchild of Siddiq Fadzil who was looking at how the creation of a prosperous community including the political aspects should be celebrated in the concept of a peaceful culture and living in harmony in building a united race.

This element is clearly spelled out by Siddiq Fadzil's words as below:

"A harmonious living culture must be based on positive attitudes towards diversity. Also as stated by Abdullah Bayyah, whereby in order to address the problem of diversity and plurality, there must be an attitude of respect and acceptance of diversity. As such, diversity is wealth and beauty. That being the reality, diversity (language and race) is part of Allah's words in highlighting the wisdom of god's creation and the incarnation of the beauty of His gifts." 
"In the event that diversity is administer and managed wisely, it shall result in productive reciprocity - complementing wealth and strength."

The colorful politics of Sabah which is weaved with various ethnics requires the four basic foundations as mentioned by Siddiq Fadzil which are:

(i) The concept of "Karamah Insaniyyah" - Humans being human regardless of race and religion are a superior being. This inclusive nobility is a direct reward from Allah (al-takrim al-Ilahiy). For everyone - Islamic and non-Islamic - shall be viewed as something precious based on their humanity. Insulting or discriminating humans based on race and religion is a wrongful act based on the concept of karamah insaniyyah. Malay-Islam people should demonstrate noble morals by respecting others of different ethnic, religion and culture. Therefore, they must possess a big heart by eliminating word and Malay phrases which insinuates hate for other races.

(ii) Diversity as "Ayati 'Llah" - When introductions are made, it shall result in the next stages where: mutual respect, mutual learning, mutual cooperation, mutual self-strengthening and mutual wealth. As such, muslim-non muslim interaction should not be limited to getting to know each other, but ta'aruf shall be the doorway towards continuous productivity and mutual benefit for all.

(iii) The Principle of Justice - The Islamic Ummah cannot only be thinking about themselves without considering justice. For example, there are Islamic people who supports gerrymandering and malapportionment in deciding election demarcation area with the consideration of benefitting the Malays, when this is obviously cheating. In issues like these, the consideration should not be based on who benefits or not, but shall be based on the principle of justice.

(iv) The Concept of Citizenship (al-Muwatanah) - Acceptance towards the concept of citizenship, equality and human rights consequentially means the rejection of all acts which are against the principle of nationality, including the act of double standard, race and religious discrimination, marginalization, suppression, expulsion etc. which is against Islam and other religions.

(v) The Concept of al-Ra iyyah - That the spirit of al-siyasah al-shar'iyyah (politics) is to protect the rights of public interest of humans as a whole, without discrimination based on race or religion. Such a definition is in line with the Islamic global values and mission towards all of mankind. The discriminative thinking based on one's race and religion is clearly not in line with the concept of al-ra iyyah and the spirit of al-siyasah al-shar iyyah which is inclusive.

The phrase below is relevant in summarizing with idea:

"Difference does not mean enemies, but cultural strength and wealth. The key to understanding the diversity of race is the recitation of 'lita 'arafu' in surah Al-Hujurat verse 13 which is usually translated as "for mutual understanding".

The foundation of diversity in the process of nation building is relevant to be associated with Fiqh Sabahi. In relation to this, a survey was conducted in Sekong to analyze in micro level, how political values based on the people without any rhetoric becomes the basis of competition for PRN 2020 at this DUN. The basis brought by the WARISAN candidate Alias Haji Sani through Fiqh Sabahi is very interesting to be analyzed.

\section{BACKGROUND OF DUN SEKONG}

DUN N53 Sekong is located under parliament P185 Batu Sapi. In therms of laction, it is located at Sabah's east district where the majority of the population is from the Bajau and Bugis ethnic. This coastal area also consists of other DUNs on interest such as DUN Senallang and Segama. DUN Senallang located in this area is contested by the president of WARISAN.

N53 Sekong consists of seven polling stations (PDM) with a total of 17,054 voters (2020). These seven PDM are at Jalan Sibuga, Kampung Gas, Jalan Batu Sapi, Tronglit, Sekong, Lupak Meluas and Pulau 
Sanghai. In terms of demography, Muslim Bumiputra consists of $75.44 \%$ of the total 16,522 voters. Aside from that, $20.03 \%$ are Chinese voters, $3.92 \%$ are Bumiputra non-Muslim and $0.6 \%$ are from other races.

\section{Competition at Sekong (1999-2018)}

DUN Sekong all this while have been a strong fortress for Barisan Nasional. Between PRU 1994 until PRU 2013, BN won comfortably at DUN Sekong. Even BN candidate, Samsudin Yahya won uncontested during PRU 2004. He then won comfortably and defended his seat during RPRU 2008 and 2013. His main opponent from opposing parties such as PBS, BERSEKUTU and then KEADILAN failed to topple BN in Sekong. This BN fortress was able to be penetrated and defeated when WARISAN was formed and later defeated the former candidate during PRU 2018.

\begin{tabular}{|c|l|c|c|c|}
\hline Year & \multicolumn{1}{|c|}{ Winner } & Party & Majority & Popular Vote \\
\hline 1994 & Datuk Nahalan Bin Damsal & BN & 1,548 & 58.7 \\
\hline 1999 & Datuk Nahalan Damsal & BN & 1,370 & 45 \\
\hline 2004 & Samsudin Bin Yahya & BN & MTB & 100 \\
\hline 2008 & Samsudin Bin Yahya & BN & 2,189 & 62 \\
\hline 2013 & Samsudin Bin Yahya & BN & 3,530 & 64 \\
\hline 2018 & Arifin Bin Asgali & WARISAN & 2,035 & 56.6 \\
\hline
\end{tabular}

Table 1: Results of DUN Sekong (1994-2018)

*Source: Summarized from all SPR results.

PRU 2018 saw for the first time BN being defeated at DUN Sekong. This BN fortress collapsed due to the huge influence of WARISAN at the Batu Sapi and Sandakan area. The emergence of WARISAN after Shafie Afdal was sacked from UMNO gave a meaningful impact on the trend of support by voters in these areas. WARISAN candidate Arifin Asgali won comfortably with a majority of 2,035 votes against his opponent who won previously with a huge majority of 3,530 votes.

\begin{tabular}{|l|c|}
\hline \multicolumn{1}{|c|}{ State } & \multicolumn{1}{c|}{ SABAH } \\
\hline \multicolumn{1}{|c|}{ Constituency (dun) } & N.43 - SEKONG \\
\hline \multicolumn{1}{|c|}{ Victorious Party } & WARISAN \\
\hline \multicolumn{1}{|c|}{ Total Votes } & 11,918 \\
\hline \multicolumn{1}{|c|}{ Majority Votes } & 2035 \\
\hline Name as Per Voting Paper & Total Votes \\
\hline Sahar Abdul Majid (PAS) & 6766 \\
\hline Arifin Bin Asgali (WARISAN) & $4705(39.5 \%)$ \\
\hline Samsudin Yahya (BN) & 48 \\
\hline Abdul Rashid Bin Abdul Rahman (STAR) & 16 \\
\hline Alias Rahmad Bin Benjamin (PKS) & 43 \\
\hline $\begin{array}{l}\text { Datu Mohd Faisal Bin Datu Bachtiyal } \\
\text { BEBAS - KAPAL TERBANG) }\end{array}$ & \multicolumn{1}{c|}{4} \\
\hline
\end{tabular}

Table 2: PRU 2018 DUN Sekong Results

*Source: SPR, 2018

Arifin Asgali's victory was a manifestation of the Malaysian political climate where the voters rejected $\mathrm{BN}$, as as a result, for the first time in history there is a government change at the federal level. BN lost $24.5 \%$ of the popular vote at Sekong where the previous bearer since PRU 2004 lost at the UMNO stronghold. WARISAN successfully obtain huge votes at two polling areas (PDM) which is at Jalan Sibuga (3,062 votes) and Jalan Batu Sapi (1,056 votes).

\section{TOWARDS ELECTION - PRE-ELECTION FIELD OBSER VATION}

A field observation was conducted with the cooperation from the local movement to evaluate the current voters need. The study conducted in August 2020 immediately after DUN Sabah was dissolved. The study has two main objectives which is to identify the criteria for the candidate which is favorable to the voters and to identify main issues that need to be addressed in the PRN Sabah 2020 at Sekong. Other than that, this study was also conducted to identify the criteria for the candidate required by the voters and whether the current bearer has the continuous support of the voters. 
The question instrument constructed uses the principle of "Keep It Short and Simple" (KISS). A total of 649 respondents participated in the study which is in the quantitative and qualitative method. The respondents were selected from all polling centers (PDM) in DUN Sekong.

The findings of the study are summarized as follows:

(i) A total of 335 respondents or $51.6 \%$ are members of a political party.

(ii) A total of 359 respondents or $55 \%$ voted for a candidate instead of a political party.

(iii) A total of 538 respondents or $82.9 \%$ stated that the candidate's religious knowledge is an important factor to be considered in their selection.

(iv) A total of 359 respondents or $54.9 \%$ feel that race/ethnic of the candidate plays an important role in their decision making.

(v) A total of 470 respondents or $72.4 \%$ respondents chose a local candidate instead of an external candidate.

(vi) A total of 543 respondents or $83.7 \%$ prefer a new face being given a chance as a candidate during PRN 2020.

In the same study, respondents feels that three main issues that must be forwarded by the candidate are people's welfare (71\%), infrastructure facility (21\%) and the issue of integrity and the right of Sabah's ownership (8\%).

Based on the popularity of all potential candidates, the respondent's choice is summarized as follows:

(i) Alias Haji Sani (33\%)

(ii) Pg. Roslan (26\%)

(iii) Arifin Asgali (16\%)

(iv) Shamsul Kelana Sam Lee (9\%)

(v) Hanafi (9\%)

(Total of $6 \%$ respondents chose to be neutral)

The findings on the popularity of the leadership as listed is shocking considering the facts that the previous bearer who is Arifin Asgali is only at the third position with $16 \%$ of respondents. This surprise is because Arifin Asgali has recently been chosen as the people's representative in the year 2018 . Furthermore, WARISAN's success via this candidate managed to provide a huge majority to defeat the candidate from BN at that time who has been people's representative for two terms. Furthermore, he was the deputy minister to the Chief Minister. In the event that he is dropped, this will surely create objection due to the fact that he has only been in office for 28 months.

\section{PRN 2020 N53 SEKONG}

After much deliberation and evaluation process, a community activist Alias Haji Sani or better known as Cikgu Alias Sani was selected to represent WARISAN. He replaced the previous bearer who is Ariffin Asgali who was dropped. It is observed that the sentiment in the field plays a vital role in the selection of the local activist in the place of the former candidate from the same party.

Alias Haji Sani was born on 17 December 1968. He obtained his highest education at Maktab Sabah (1987). Earlier, he started his career at Lembaga Perindustrian Kayu Malaysia for two years (19931995). Subsequently, he was the principle at Institut pengajian As-Salam and Sekolah Menengah (Swasta) As-Salam Sandakan from 1995 until he was chosen as a candidate in PRN Sabah 2020. He was also the Chairman of the management agency of As-Salam

He is known as a political activist with active participation in the community activities especially at Batu Sapi and Sandakan. Among his involvement in NGO is as the Youth Chairman of Batu Sapi (2018), Secretary of Bani Fateh Sandakan (2015), advisor for charitable organization Imam An-Nawawi Sabah (2017) and advisor for K-Marhaens Sandakan (2018).

In politics, Alias Haji Sani among others have held the position of Deputy Chairman and Strategy Director for the Amanah Party (AMANAH) Sabah (2015-2017). Among his political involvement at 
that time is to assist the campaign for Pakatan Harapan especially AMANAH during the Sarawak election in the year 2016.

He then decided to join WARISAN officially on 1 February 2018. His involvement in WARISAN is due to the common desire with the main local party in line with the idea of Fiqh Sabahi. WARISAN is of the opinion that the involvement of the second person in AMANAH Sabah will definitely have a positive impact in strengthening the party. He was then selected as the strategic director for WARISAN for the Batu Sapi parliament. His main achievement includes winning all 3 seats contested by WARISAN at the Batu Sapi Parliament during The General Election 2018.

Even though Alias Haji Sani does not hold any position in the leadership of WARISAN Batu Sapi, he has a large influence and significance in Batu Sapi. As a leader, he is well known due to his excellent networking with the Bumiputera and non-Bumiputera ethnic community. His experience at Assalam as the administrator and educator also earned him the name "Cikgu Alias" which was very popular. Also, his large family networking at the area of Batu Sapi especially at Karamunting, Kampung Bokara, Lupak Meluas, Kampung Melanta, Sundang, Sibuga, Taman Mawar and Kampung Gas has provided a huge advantage compared to other candidates who are contesting.

The candidate nomination saw a 6 cornered contest where WARISAN is faced with candidate BN, PCS, LDP, PPRS and USNO. On paper, the fierce competition is expected betweenWARISAN, BN and PCS for the seat in DUN Sekong. Two main candidates seen with the potential to challenge the candidate from WARISAN are from BN and PCS. BN candidate Hazulizah Zaini aged 35 with a Bachelor's Degree in the field of History from UMS. She was the (JASA) officer for DUN Sekong. In politics, she was the deputy of the UMNO Movement and leader of Puteri UMNO in Batu Sapi (since 2013).

The candidate for PCS is Sitti Nurul Ain Sahidah Binti Pitting who is a native of Kamoung/ Istimewa/ Kampung Pukul at Sekong. She is also the daughter to the former member of parliament Kinabatangan, Allahyarham YB Pitting bin Haji Mohd Ali. Who was a lawyer by profession.

\section{WARISAN'S CAMPAIGN IN DUN SEKONG}

In general, the main focus of the GRS campaign is the allegation on the failure of Shafie Apdal to bring development as a whole to Sabah in his 26 months in heading the state government. To be specific, the focus of the GRS campaign is on the following issues:

(i) Lack of basic infrastructure provided under the WARISAN/PH government.

(ii) The cold relationship between the state government and federal government as a result of differences between political party's administration.

(iii) Failure of the government to revive the weak Sabah economy.

(iv) Failure of the government to resolve the issue of illegal foreign immigrants to Sabah.

As a retaliation to the GRS campaign, WARISAN-Plus has raised the issue pertaining to the foundation needs of the Sabah people. Among the emphasis of WARISAN in PRN is to conserve the development and wealth of Sabah. Among the emphasis are:

(i) Empowerment of the basic rights of the Sabahan people.

(ii) To guarantee ownership of Customary Land (Tanah Adat) and the ownership rights of Bumiputra Sabah.

(iii) To streamline the socioeconomic programs for youth and women.

For DUN Sekong, the GRS candidate represented by BN gave emphasis on the issues of education. This is taking into consideration the experience of the $\mathrm{BN}$ candidate in the field as a community progress mobilizer and due to the factor that the opponent from WARISAN has the experience from Sekolah Assalam. Based on data from SPR, the total number of voters at DUN Sekong for PRN 2020 was 17,054. There are 7 polling centers (PDM) under 35 localities. In short, the total voters for DUN Sekong can be detailed according to the PDM as follows: 


\begin{tabular}{|l|c|}
\hline \multicolumn{1}{|c|}{ PDM } & Total Voters \\
\hline 001 - Jalan Sibuga & 5497 \\
\hline 002-Kg Gas & 2685 \\
\hline 003 - Jalan Batu Sapi & 3201 \\
\hline 004 - Tronglit & 939 \\
\hline 005 - Sekong & 929 \\
\hline 006 - Lupak Meluas & 3367 \\
\hline 007 - Pulau Sanghai & 442 \\
\hline Grand Total & $\mathbf{1 7 5 0 4}$ \\
\hline
\end{tabular}

Table 3: Total Voters by PDM

*Source: SPR

Among the main challenges of the campaign team for Alias Haji Sani is the cooperation from the supporters of the former bearer from WARISAN. The possibility of protest votes and challenges on how to strengthen the campaign missionary at all locations. The candidate is also faced with the media attack including in YouTube which tried to damage the reputation and character as early as the first day of the campaign. In fact, Alias Haji Sani's reputation was also defended by the WARISAN main leadership who is Shafie Apdal through his stern statement in the newspaper. The candidate also lodged a police report to enable investigation to be opened to obtain the real picture on the personal attack. Obviously, Alias Haji Sani's campaign was not effective and the campaign was fully accepted by the community around Sekong. Alias Haji Sani's campaign group employed an interesting approach in winning the PRN.

The campaign conducted by Alias Haji Sani's group shows positive opportunities for their candidate to win and defended the majority obtained by WARISAN before this. Other than the typical pattern of campaigns, his campaign uses the concept of micro analysis based on PDM. The candidates' advantage as an activist including through the Belia Batu Sapi and as a main character at Sekolah As-Salam becomes a big advantage compared to the competitor. This campaign was conducted under limited funds, missionary as well as group support from the previous candidate which was dropped. However, his spirit as the person selected by the people is a narrative that provides a positive impact in this competition. This is explained in the slogan "Kita Rakyat" which is associated with Alias Haji Sani.

\begin{tabular}{|l|c|c|c|}
\hline \multicolumn{1}{|c|}{ PDM } & $\begin{array}{c}\text { Total } \\
\text { Voters }\end{array}$ & $\begin{array}{c}\text { Projected voters } \\
\text { Turn-out } \\
(\mathbf{6 5 \% )}\end{array}$ & $\begin{array}{c}\text { Projected Voters } \\
\text { for WARISAN }\end{array}$ \\
\hline 001 - Jalan Sibuga & 5497 & 3573 & $2858(80 \%)$ \\
\hline 002 - Kg Gas & 2685 & 1745 & $698(40 \%)$ \\
\hline 003 - Jalan Batu Sapi & 3201 & 2081 & $832(40 \%)$ \\
\hline 004 - Tronglit & 939 & 610 & $244(40 \%)$ \\
\hline 005 - Sekong & 929 & 600 & $242(40 \%)$ \\
\hline 006 - Lupak Meluas & 3367 & 2189 & $1095(50 \%)$ \\
\hline 007- Pulau Sanghai & 442 & 287 & $115(40 \%)$ \\
\hline Grand Total & $\mathbf{1 7 5 0 4}$ & $\mathbf{1 1 0 8 5}$ & $\mathbf{6 0 8 4}(\mathbf{5 4 . 9 \% )}$ \\
\hline
\end{tabular}

Table 4: Projection of WARISAN's target Voters

*Source: WARISAN field campaign

The WARISAN candidate has a large influence at the two PDM areas which are Jalan Sibuga and Lupak Meluas. These two areas have the highest number of voters which is 8,864 which covers half or $50.6 \%$ of the grand total of voters. In relation to this, his campaign group targeted 4,000 votes to be obtained from these two areas to balance the strength of BN candidate at 5 other PDM. The campaign at Jalan Sibuga also emphasized on the area where there are a large number of voters such as Taman Mawar (2,881 pemilih).

Alias Haji Sani's campaign team also proved successful in making the assumption of the popular vote obtained by their candidate. He managed to obtain $55 \%$ of the popular vote and this result is in line with the expectation of the campaign team which is $54.9 \%$. As a fact, the real vote was only short of 147 from the expected vote during the campaign which was 6084 votes compared to the actual vote of 5937. 
As a candidate with a religious background, Alias Haji Sani supported the idea of Fiqh Sabahi. This idea was earlier mooted since 2017 with main emphasis on the aspect of legislation, preaching and religious education which is needed to be adapted to the situation where there are various ethnic groups in Sabah. This is best used through the implementation of political ideas and values under the madani community framework. The advantage of presenting the khutbah and tazkirah was an asset in attracting support from the Muslim voters. He also uses the concept of gentlemen politics without the necessity to use slander and personal attacks to win the election. Healthy campaign without running down the opponent becomes one of the main strengths during the campaign at DUN Sekong.

The emphasis on hs campaign is also focused on his personal background as an activist and educator. Alias Haji Sani was known as a community activist for so long. This made the non-Muslim voters see him as their best candidate. Nearly $24 \%$ of the voters at Sekong are non-Muslim and his role all this while at Batu Sapi is an advantage. In a situation where more than $60 \%$ of the Sekomng population under B-40, various assistance and activities to assist the people were conducted by this candidate especially through the networking NGO-NGO with him. This is not something new conducted by Alias Haji Sani where he has been doing this for a long time and proven to get the attention of the people at Sekong during the campaign period. The popularity and togetherness of Alias Haji Sani at Sekong proved to be an advantage compared to other candidates. For example, a survey conducted online during the campaign period showed that Alias Haji Sani obtained $63.31 \%$ from the total of 1,687 respondents who participated in the survey.

\section{ANALYSIS AND RESULTS}

Even though WARISAN-PLUS failed to defend the state government which was won during PRU 2018 , clearly Sekong was able to be defended. The success with the majority 1,599 is not just a narrative because Sekong is a stronghold for WARISAN, but because of various factors including the personality of the new candidate selected by the party.

\begin{tabular}{|c|c|c|}
\hline State & \multicolumn{2}{|c|}{ SABAH } \\
\hline Dun & \multicolumn{2}{|c|}{ N.53 - SEKONG } \\
\hline Winning Party & \multicolumn{2}{|c|}{ WARISAN } \\
\hline Total Voters & \multicolumn{2}{|c|}{10,780} \\
\hline Majority Votes & \multicolumn{2}{|c|}{1,599} \\
\hline \multicolumn{2}{|c|}{ Name as on Voting Paper } & Total Votes \\
\hline \multicolumn{2}{|c|}{ Alias Bin Sani (WARISAN) } & $5937(55 \%)$ \\
\hline \multicolumn{2}{|c|}{ Hazulizah Mohd Dani (BN) } & $4338(40 \%)$ \\
\hline \multicolumn{2}{|c|}{ Sitti Nurul Ain Sahidah Bt Pitting (PCS) } & 253 \\
\hline \multicolumn{2}{|c|}{ Mohd Fazil Bin Ajak (LDP) } & 102 \\
\hline \multicolumn{2}{|c|}{ Abidin Bin Sukor (PPRS) } & 87 \\
\hline \multicolumn{2}{|c|}{ Saran Bin Jumdail (USNO) } & 63 \\
\hline
\end{tabular}

One interesting fact is that WARISAN won and defended Sekong with a new candidate during the condition where the party failed to defend the state government. Alias Haji Sani won the DUN Sekong seat with the majority of 1,599 votes. He managed to obtain 55\% popular votes compared to the nearest competitor Hazulizah Mohd Dani who obtained 4,338 votes or $40 \%$ popular vote. All the other four candidates lost their deposit money.

When observed, the percentage of popular votes under the new WARISAN candidate is only short of $1.6 \%$ compared to the previous candidate at Sekong before this. This percentage is high when taking into consideration the low voter turnout percentage and election being held during the Covid-19 pandemic. The votes from Chinese such as from Sibuga and on the fence voters have chosen the WARISAN candidate. Chinese voters are seen as voting in bulk and selected Alias Haji Sani based on the local issues package brought by him. On the fence voters which are not inclined to any party clearly chose the candidate with the best package. 


\begin{tabular}{|l|c|c|c|c|c|}
\hline \multicolumn{1}{|c|}{ PDM } & $\begin{array}{c}\text { Total } \\
\text { Voters }\end{array}$ & $\begin{array}{c}\text { Targeted Voters } \\
\text { Turnout } \\
(\mathbf{6 5 \%})\end{array}$ & $\begin{array}{c}\text { Actual Votes } \\
\text { Received }\end{array}$ & $\begin{array}{c}\text { Projected Voters } \\
\text { for WARISAN }\end{array}$ & $\begin{array}{c}\text { Actual } \\
\text { Votes for } \\
\text { WARISAN }\end{array}$ \\
\hline 001 - Jalan Sibuga & 5497 & 3573 & 3321 & $2858(80 \%)$ & $2653(80 \%)$ \\
\hline 002 - Kg Gas & 2685 & 1745 & 1765 & $698(40 \%)$ & $780(44 \%)$ \\
\hline 003 - Jalan Batu Sapi & 3201 & 2081 & 1787 & $832(40 \%)$ & $928(52 \%)$ \\
\hline 004 - Tronglit & 939 & 610 & 639 & $244(40 \%)$ & $250(40 \%)$ \\
\hline 005 - Sekong & 929 & 600 & 552 & $242(40 \%)$ & $183(33 \%)$ \\
\hline 006 - Lupak Meluas & 3367 & 2189 & 2113 & $1095(50 \%)$ & $955(35 \%)$ \\
\hline 007 - Pulau Sanghai & 442 & 287 & 333 & $115(40 \%)$ & $100(30 \%)$ \\
\hline Grand Total & $\mathbf{1 7 5 0 4}$ & $\mathbf{1 1 0 8 5}$ & & $\mathbf{6 0 8 4 ( 5 4 . 9 \% )}$ & \\
\hline
\end{tabular}

Table 6: Results based on WARISAN's Final Party Report

*Source: WARISAN's Final Party Report - N53 Sekong Results

From the total 171 postal votes received, Alias Haji Sani obtained 88 votes compared to BN candidate who obtained 80 votes. Only the PCS candidate, aside from two other candidates, managed to obtain 3 postal votes. From the total 5 PDM, the WARISAN candidate managed to overcome the BN candidate in Jalan Sibuga (majority 2044 votes) and at Jalan Batu Sapi (in excess of 79 votes) only. However, as a whole, the strength of voters in PDM Jalan Sibuga where the BN candidate only obtained 609 votes or $18 \%$ of the total votes has a big impact to the final result. The interesting result at PDM Batu Sapi also with WARISAN getting 535 votes compared to the earlier expectation of $40 \%$ made it difficult for BN to increase the overall vote. The Malay voters are also seen accepting the WARISAN candidate where Alias Haji Sani lost marginally in the area where there is a majority of Malays such as at PDM Kampung Gas (BN in excess of 128 votes) and PDM Sekong (BN in excess of 167 votes). Even though Alias Haji Sani has a religious background, Chinese voters are seen to have no problem in supporting him. He won at all PDM and channels with the majority of Chinese ethnic such as PDM Jalan Sibuga.

To summarize, there are various attracting factors that resulted in the success of maintaining this seat.

(i) The candidate's popularity as a community activist and educator who is which is favorable to many races has given him an advantage.

(ii) The candidate used social media effectively. Alias Haji Sani's page with the theme Bina Semula Sekong obtained 10,461 likes and followers of 11,630.

(iii) Sekong as a stronghold of Malay Bumiputera. His advantage as a candidate with religious background is something interesting and became the choice for voters and reduced the vote for $\mathrm{BN}$ in areas with majority of Malay Bumiputera.

(iv) Gentlemen Politics advocated by Alias Haji Sani was well accepted by non-Muslim voters, which carries the aspect of high integrity.

\section{CONCLUSION}

Malaysia and Sabah need Gentlemen Politics. Political competition must have political value. The element of Gentlemen Politics is anchored on political character, manners and cultivation in upholding new political narrative in this country. It is obvious that Malaysian politics and Sabahan politics has a political pattern which is colourful, however not necessarily all aspects of it can be proud of. It is known for political parties which always challenge acceptance based on integrity and justice to the voters.

The victory by Alias Haji Sani at DUN Sekong during PRN 2020 signifies the acceptance of the people towards Gentlemen Politics. Voters not only look at the party, but also the candidate brought forward. The main unique factor during election at Sekong is the acceptance of voters not only based on the party but more to the candidate's character. What happened in DUN Sekong has to be seen from the local's perspective and not just Sabah's political scenario in general.

The question of whether the victory in N53 Sekong is something that happens only once shall be decided by the people of Sabah alone. People of Sabah has gone through a very interesting political process, full of drama and never-ending political conflict every time there is a PRU or PRN. Gentlemen Politics 
advocated by Alias Haji Sani is something fresh and in line with Fiqh Sabahi which is advantageous to all. It is time for Malaysia and Sabah to have leaders who are gentlemen who not only have brains but also have character.

\section{REFERENCE}

Alias Haji Sani, https://www.facebook.com/BinaSemulaSekongN53/about/?ref=page_internal, 23 September 2020. Alias Sani Supporter, https://www.facebook.com/N53SEKONG/photos/pcb.103308344868904/103308138202258/

Arif Aizudin Azlan \& Zulkanain Abdul Rahman (2020). "Teori Persaingan Parti Dalam Pilihan Raya Kecil Parlimen Batu Sapi, Sabah, Malaysia”, Jurnal UMCedel, Vol. 4, Bil. Jan-Dis 2020, hlm. 19-38.

"Calon BN DUN Sekong, Hazulizah fokus pendidikan, kebajikan rakyat", Utusan Borneo, 11 September 2020, https://www.utusanborneo.com.my/2020/09/11/calon-bn-dun-sekong-hazulizah-fokus-pendidikan-kebajikan-rakyat

Chab, T.S. (2020), "Warisan Plus in Government: A Retrospective from the Campaign and Beyond", dlm. Welsh, B. , Somiah, V. \& Benjamin YH Loh (eds). (2021). Sabah From The Ground, The 2020 Elections \& The Politics of Survival. PJ: SIRD, hlm. 21-38.

"DUN Sabah bubar hari ini.", Berita Harian, 30 Julai 2020. https://www.bharian.com.my/berita/nasional/2020/07/716316/dun-sabah-bubar-hari-ini

FB Barisan Nasional, 13 September 2020, https://www.facebook.com/barisanasional/posts/ini-calon-kitahazulizahmohd-dani-calon-barisan-nasional-untuk-rakyat-sabah-n53-/3247878831992946/.

FB Parti Cinta Sabah N53 Sekong, 11 September 2020, https:/www.facebook.com/100291628496030/posts/memperkenalkan-calon-parti-cinta-sabah-saudari-sitti-nurul-ain-sahidah-binti-pit/100294258495767/

Govindasamy, A.R. (2020), "The Sabah State election: A Narrow Win and Precarious Mandate for the New Government", ISEAS, Issue: 2020, No. 131.

"I'm not a terrorist, says Sekong candidate", The Star, 14 September 2020. https://www.thestar.com.my/news/nation/2020/09/14/im-not-a-terrorist-says-sekong-candidate.

Joeman, B, Dino, N. dan Asraf Sharafi (2020), "Voices of Civil Society Organisations in Sabah Politics", dlm. Welsh, B. , Somiah, V. \& Benjamin YH Loh (eds). (2021). Sabah From The Ground, The 2020 Elections \& The Politics of Survival. PJ: SIRD, hlm. 83-94.

Junaidi Awang Besar \& Amer Saifude Ghazali, "Pilihan Raya Kecil Kimanis, Antara identifikasi Parti Dengan Kelangsungan Politik Pembangunan", ”, Jurnal UMCedel, Vol. 4, Bil. Jan-Dis 2020, hlm. 76-94.

'I am not a terrorist', says Warisan's Sekong candidate", The Star, 13th September 2020, https://www.thestar.com.my/news/nation/2020/09/13/039i-am-not-an-extremist039-says-warisan039ssekong-candidate.

ILHAM Centre (2020), Ringkasan Eksekutif Pola Pengundian Pilihan Raya Negeri Sabah 2020, 25 September, 2020.

"Lima wakil rakyat Warisan digugurkan untuk beri laluan muka baru". Astro Awani, 10 September 2020, https://www.malaysiakini.com/news/542093.

Mohd Fudzail Mohd Nor (2021), "Kepelbagaian menurut Siddiq Fadzil”, Malaysiakini, 2 September 2021. https://www.malaysiakini.com/news/589586.

Mohd Noor Mat Yazid \& Md Shafie Abdul Rahim (2019). "Berakhirnya Simpanan Tetap Barisan Nasional dan Bermulanya Kuasa Politik Baru di Negeri Sabah”, dlm. Zulkanain Abdul Rahman, Rosmadi Fauzi dan Amer Saifudi Ghazali (peny.), Pilihan Raya Umum ke 14, Isu dan Cabaran Malaysia Baharu. KL: Penerbit UM.

Mohd Noor Mat Yazid (2019). "Pencapaian BN dalam Parlimen Negeri Sabah dalam PRU 12, 13 dan 14", dlm. Zulkanain Abdul Rahman, Rosmadi Fauzi dan Amer Saifudi Ghazali (peny.), Pilihan Raya Umum ke 14, Isu dan Cabaran Malaysia Baharu. KL: Penerbit UM.

Mohd Rahimin Mustafa (2020), "Islam and Muslim Politics in Sabah's 2020 State Election”, dlm. Welsh, B., Somiah, V. \& Benjamin YH Loh (eds). (2021). Sabah From The Ground, The 2020 Elections \& The Politics of Survival. PJ: SIRD, hlm. 305-327.

"Musa dakwa peroleh majoriti mudah bentuk kerajaan baharu Sabah.”, Berita Harian, 29 Julai 2020. https://www.bharian.com.my/berita/nasional/2020/07/716142/musa-dakwa-peroleh-majoriti-mudah-bentuk-kerajaan-baharusabah

"Parti Warisan Sabah is new name of Shafie-led party", Bernama. The Sun. 17 Oktober 2016.

"Pemimpin parti Amanah sertai Warisan kerana ingin parti tempatan", Borneo Today, 2 Februari 2018, https://www.borneotoday.net/pemimpin-parti-amanah-sertai-warisan-kerana-ingin-parti-tempatan/.

"Perkhidmatan singkat sebagai ADUN, banyak perancangan tertangguh", Utusan Borneo, 15 Ogos 2020, https://www.utusanborneo.com.my/2020/08/15/perkhidmatan-singkat-sebagai-adun-banyak-perancangantertangguh.

“PRN Sabah: WARISAN yakin rakyat faham visi, misi dibawa”,Berita Harian. 16 September 2020, https://www.bharian.com.my/berita/nasional/2020/09/731943/prn-sabah-warisan-yakin-rakyat-faham-visi-misi-dibawa

Profile Alias Haji Sani (WARISAN) 
"Sabah lists 42 ethnic groups to replace 'lain-lain' race column". The Malay Mail, 13 February 2015, http://www.themalaymailonline.com/malaysia/article/sabah-lists-42-ethnic-groups-to-replace-lain-lain-race-column

"Sekong candidate not a terrorist, says Shafie", Daily Express, 15 September 2020. http://www.dailyexpress.com.my/news/158384/sekong-candidate-not-a-terrorist-says-shafie.

“Sekong candidate lodges police report over YouTube video alleging terrorist links.”, The Star, 16 September 2020. https://headtopics.com/my/sekong-candidate-lodges-police-report-over-youtube-video-alleging-terroristlinks-15678078

“Shafie Apdal angkat sumpah Ketua Menteri”, Berita Harian, 12 Mei 2018, https://www.bharian.com.my/berita/politik/2018/05/424866/shafie-apdal-angkat-sumpah-ketua-menteri

Shaharuddin Badaruddin (2016). Masyarakat Madani dan Politik. SA: IDE.

Siddiq Fadzil (2016), Pembinaan Bangsa : Kepelbagaian dalam Bingkai Kesatuan. SA: IDE.

Siddiq Fadzil (2019). Membina Kesatuan Bangsa: Kerukunan Hidup Bersama Dalam Budaya Damai. SA: IDE.

SPR, 2020

Welsh, B. , Somiah, V. \& Benjamin YH Loh (eds). (2021). Sabah From the Ground, The 2020 Elections \& The Politics of Survival. PJ: SIRD. 